(C) Хромченко О. В., 2019 p.

https://orcid.org/0000-0001-7437-6041

DOI: $10.34142 / 23128046.2019 .46 .12$

О. В. Хромченко

\title{
ПСИХОЛОГО-ПЕДАГОГІЧНІ ЗАСОБИ ПІДГОТОВКИ МАЙБУТНІХ УЧИТЕЛІВ-ФІЛОЛОГІВ ДО ПЕДАГОГІЧНОЇ КОМУНІКАЦІЇ
}

Професійно-педагогічна комунікаиія виступає невід'ємним компонентом діяльності вчителя. Питання розвитку комунікативних умінь майбутніх фахівиів залишається недостатньо розробленим. Мета статті полягає у висвітленні психолого-педагогічної суті поняття «педагогічна комунікачія» та засобів підготовки майбутніх учителів до здійснення окресленої діяльності. Сформульована мета передбачає вирімення таких завдань: конкретизувати поняття «педагогічна комунікація»; виявити особливості иьього виду діяльності; розробити психолого-педагогічні засоби формування готовності вчителів-філологів до педагогічної комунікації. $У$ статті розкрито педагогічну суть поняття «педагогічна комунікація» в аспекті підготовки майбутніх учителів-філологів до участі в цъьому виді діяльності. Висвітлено результати аналізу вітчизняних та зарубіжних наукових джерел стосовно суті окресленого феномена. 3'ясовано, щио педагогічна комунікація спрямована на обмін інформачією, створення здорового психологічного клімату, дозволяє максимально використати в навчальному прочесі професійні та особистісні якості викладача. Ефективність педагогічної комунікації визначається рівнем сформованості комунікативних умінь та навичок майбутніх фахівців (уміння управляти своєю поведінкою, розуміти особистість учня, будувати власне мовлення) та особистісних якостей (відвертість та довіра у спілкуванні, неконфліктність, емпатійність, толерантність, ініціативність). Ресурсом підготовки майбутніх учителів до педагогічної комунікачії пропонується впровадження в навчальний процес педагогічних ситуацій-вправ комунікативного спрямування та методу проектів. Зазначені педагогічні засоби сприяють формуванню комунікативних умінь, розвитку рефлексивних та творчих здібностей, підвищенню пізнавального інтересу, дають можливість майбутнім фахівиям прогнозувати та змоделювати власну поведінку.

Ключові слова : педагогічна комунікація, педагогічне спілкування, підготовка, готовність, компетентність.

Khromchenko O. V. Psychological and pedagogical means of training of future teachers-philologists for pedagogical communication. Professionalpedagogical communication functions as an integral part of a teacher's activity. The problem of developing communicative skills of future specialists remains 
developed. The objective of the article is to highlight the psychological and pedagogical nature of the concept "pedagogical communication" and the means of training future teachers in order for them to be able to implement the defined activities. The tasks are as follows : to specify the concept of "pedagogical communication"; to identify the features of this type of activity; to develop psychological and pedagogical means of professional training the future teachersphilologists for pedagogical communication.The article reveals the pedagogical essence of the concept "pedagogical communication" in the aspect of professional training of the future teachers of philology for participation in this type of activity. The results of the analysis of domestic and foreign scientific sources concerning the essence of the outlined phenomenon are highlighted. Pedagogical communication is aimed at the exchange of information, the creation of a healthy psychological climate, allows maximum use of the professional and personal qualities of the teacher in the process of teaching and learning. The efficacy of pedagogical communication is determined by the level of formation of communicative abilities and skills of the future specialists (ability to manage their behavior, understand the student's personality, build their own speech) and personal qualities (openness and trust in communication, non-conflict, empathy, tolerance, initiative).We propose the introduction of the pedagogical situational exercises of a communicative orientation and the project method in the educational process during the teaching of professionally-oriented disciplines as a resource for the training of future teachers for pedagogical communication. The touched upon pedagogical means will promote the formation of communicative skills, development of creative abilities, the increase of cognitive interest; enable future specialists to predict and simulate their own behavior; contribute to the development of their reflexive abilities.

Keywords : pedagogical communication, training, competence, readiness.

Вступ. У Національній стратегії розвитку освіти в Україні на період до 2021 року зазначено, що результатом іiі реалізації має бути підготовка та виховання педагогічних кадрів, які здатні працювати на засадах інноваційних підходів до організації навчально-виховного процесу, власного творчого професійного зростання впродовж усього життя. У Законі України «Про вищу освіту», Національній доктрині розвитку освіти України у XXI столітті визначено вимоги до системи знань та компетентностей майбутніх фахівців.

Професійно-педагогічна комунікація виступає невід'ємним компонентом діяльності вчителя. Проте, питання розвитку комунікативних умінь майбутніх фахівців залишається недостатньо розробленим. Окреслена проблема розглядалася в таких аспектах: структура комунікативної 
компетентності майбутнього вчителя (Н. Бібік, Н. Волкова, Л. Гейхман, О. Жирун, Н. Морева, Л, Поварніцина); стилі професійного педагогічного спілкування (В. Кан-Калік, Г. Коваль); формування комунікативної культури вчителя (А. Брушлинський, Т. Гоффманн, М. Лазарєва, І. Шаповалова).

Мета та завдання. Мета статmі полягає у висвітленні психологопедагогічної суті поняття «педагогічна комунікація» та засобів підготовки майбутніх учителів до здійснення окресленої діяльності. Відповідно до мети дослідження було визначено такі завдання: конкретизувати поняття «педагогічна комунікація»; виявити особливості цього виду діяльності; розробити психолого-педагогічні засоби формування готовності вчителівфілологів до педагогічної комунікації.

Методи дослідження. Для вирішення окреслених завдань використано такі методи дослідження: теоретичні: аналіз наукових джерел з педагогіки та психології з метою розкриття суті поняття «педагогічна комунікація»; аналіз освітніх програм, навчально-методичних посібників з означеної проблеми.

Результати. Аналіз наукової літератури (Т. Дрідзе, М. Каган, Д. Лауріллард, $\quad$ С. Пілішек) виявив, що поняття «спілкування» та «комунікація» визначаються як рівнозначні, тотожні терміни. У словнику педагогічних термінів С. Гончаренко, спілкування визначається як взаємодія людей, у процесі якої здійснюється обмін думками, способами поведінки, а також задовольняються потреби особистості (Honcharenko, 1997). 3 точки зору М. Кагана, спілкування має практичний, матеріальний, духовний, інформаційний і практично-науковий характер. У педагогічній діяльності спілкування спрямоване на вирішення різноманітних навчальних завдань, забезпечує розвиток особистості учнів, виступає засобом організації відносин між учнями та вчителем (Laurillard, 2012). М. Каган розглядає педагогічну комунікацію як різновид педагогічної діяльності, основною функцією якої виступає вплив викладача на студента за допомогою передачі знань, відомостей та уявлень. 
Досліджуючи проблему змісту готовності вчителя до педагогічної діяльності, Н. Мойсеюк визначає комунікативні вміння як складовий елемент практичної частини змісту зазначеного поняття. Серед умінь педагогічного спілкування автор звертає увагу на такі: вміння відповідно до потреб класу обирати способи звертань; керувати ініціативою в класі; забезпечувати атмосферу благополуччя (Moiseiuk, 2007).

В. Ортинський виокремлює комунікативну компетенцію як складову професійної кваліфікації науково-педагогічного працівника. Науковець підкреслює, що окреслена компетенція виявляється саме в здатності майбутнього вчителя здійснювати педагогічне спілкування. Автор визначає професійно-педагогічне спілкування як систему прийомів соціальнопсихологічної взаємодії педагога та студентів, що спрямовані на обмін інформацією, розв'язання різноманітних завдань, всебічний розвиток особистості вихованців, створення умов для реалізації їх творчих здібностей (Ortynskyi, 2009). Таким чином, В. Ортинський звертає увагу на важливість педагогічного спілкування як засобу організації та стимулювання діяльності тих, хто навчається.

Аналогічний підхід до функцій педагогічного спілкування простежується у дослідженні В. Лозової, Н. Волкової, О. Малихіна, А. Троцко. Науковці звертають увагу на те, що комунікативна компетентність педагога спрямована на підвищення рівня «особистісно розвивального середовища класу» (Lozova, 2011), створення сприятливого психологічного клімату (Edge, Garton, 2012), регулювання педагогічних відносин (Bondareva, 2010).

Узагальнений аналіз наукових позицій щодо суті поняття «педагогічна комунікація» у контексті різних наукових підходів представлений в таблиці 1.

Таблиия 1.

Педагогічна комунікація 


\begin{tabular}{|c|c|c|}
\hline Науковець & Напрям дослідження & Варіант визначення \\
\hline Л. Бондарєва & $\begin{array}{l}\text { Роль викладача як } \\
\text { суб’єкта педагогічної } \\
\text { комунікації }\end{array}$ & $\begin{array}{l}\text { Засіб досягнення взаєморозуміння в колективі, } \\
\text { впливу на особистісне зростання учнів } \\
\text { (Bondareva, 2010). }\end{array}$ \\
\hline Н. Волкова & $\begin{array}{l}\text { Професійно-педагогічна } \\
\text { комунікація }\end{array}$ & $\begin{array}{l}\text { Система безпосередніх чи опосередкованих } \\
\text { зв’язків, взаємодій педагога, що реалізуються за } \\
\text { допомогою вербальних та невербальних засобів, } \\
\text { засобів комп'ютерної комунікації та мають на } \\
\text { меті взаємообмін інформацією, управління } \\
\text { процесом комунікації (Volkova, 2006). }\end{array}$ \\
\hline О. Жирун & $\begin{array}{l}\text { Педагогічна комунікація } \\
\text { в аспекті професійної } \\
\text { ідентичності }\end{array}$ & $\begin{array}{l}\text { Ідейно-моральна категорія, що вимагає від } \\
\text { особистості педагога усвідомлення власних } \\
\text { потреб, а також норм і цінностей інших } \\
\text { соціальних групп (Zhyrun, 2010). }\end{array}$ \\
\hline I. Когут & $\begin{array}{l}\text { Формування } \\
\text { професійно-педагогічної } \\
\text { комунікативної } \\
\text { компетентності } \\
\text { майбутнього вчителя }\end{array}$ & $\begin{array}{l}\text { Форма здійснення педагогічного процесу, що } \\
\text { проявляється у пошуку змісту та способу } \\
\text { передачі навчальної інформації, у творчості } \\
\text { педагогічної взаємодії (Kohut, 2015). }\end{array}$ \\
\hline $\begin{array}{l}\text { О. Малихін, I. } \\
\text { Павленко }\end{array}$ & $\begin{array}{l}\text { Проблеми } \quad \text { культури } \\
\text { педагогічного } \\
\text { спілкування }\end{array}$ & $\begin{array}{l}\text { Особливий вид творчої діяльності; система } \\
\text { прийомів взаємодії педагога й учнів, змістом } \\
\text { якої є обмін інформацією, пізнання одне } \\
\text { одного (Lozova, 2011). }\end{array}$ \\
\hline Г. Мешко & $\begin{array}{l}\text { Спілкування як основа } \\
\text { педагогічної діяльності }\end{array}$ & $\begin{array}{l}\text { Система прийомів та способів соціально- } \\
\text { психологічної взаємодії педагога та учнів, } \\
\text { спрямована на обмін інформацією, здійснення } \\
\text { виховного впливу та налагодження взаємин } \\
\text { (Meshko, 2012). }\end{array}$ \\
\hline
\end{tabular}

Обговорення. Аналіз наукових позицій щодо визначення суті поняття «педагогічна комунікація» дає змогу дати таке визначення цього поняття: це особливий вид взаємодії викладача та учнів, що спрямований на взаємообмін думками, почуттями та знаннями, оптимізацію навчальної діяльності, налагодження взаємин у колективі. Отже, педагогічна комунікація спрямована на обмін інформацією, створення здорового психологічного клімату, дозволяє максимально використати в навчальному процесі професійні та особистісні якості викладача. 
Наголосимо, що ефективність педагогічної комунікації визначається рівнем сформованості комунікативних умінь та навичок майбутніх фахівців (уміння управляти своєю поведінкою, розуміти особистість учня, будувати власне мовлення) та особистісних якостей (відвертість та довіра у спілкуванні, неконфліктність, емпатійність, толерантність, ініціативність).

Проте, поширеним освітнім явищем виступають труднощі спілкування вчителів, тобто комунікативні бар'єри (Б. Айсмонтас, Н. Волкова, В. Лабунська), що ускладнюють процес сприйняття учнями навчальної інформації, заважають їх пізнавальній діяльності, формуванню як гармонійних особистостей, унеможливлюють адекватні поведінкові реакції тих, хто навчається. Серед факторів, що спричиняють виникнення бар'єрів комунікації, фахівці називають такі групи: - особистісні: невпевненість у собі, замкнутість, нерішучість, безініціативність, залежність від зовнішніх обставин та оцінок; - фізичні: неправильна організація фізичного простору, що зумовлює ізольованість учителя від учнів; - соціально-психологічні: поганий контакт із учнями, невпевненість у своїх знаннях і вміннях.

Науковці (В. Кан-Калік, Н. Кічук, І. Когут, О. Леонтьєв, В. Лозова, А. Троцко) розробили систему вправ, які, з одного боку, мають на меті практичне оволодіння майбутніми вчителями технікою й технологією педагогічної комунікації, а, з іншого, - системою спілкування в конкретній педагогічній ситуації. До першої групи автори відносять вправи, що спрямовані на розвиток техніки та логіки мовлення, міміки та пантоміміки, м’язової свободи в педагогічній діяльності: «майстерність переконуючого впливу» (учасники готують виступ із певної тематики, пояснюють новий матеріал, критерієм оцінки виступають логіка викладення матеріалу, культура мовлення, зовнішній вигляд), «вміння слухати» (сприяє перевірці та розвитку уважності), «катастрофа у пустелі» (має на меті вироблення навичок поведінки в дискусії), «без маски» (завдання передбачає визначення щирості гравця в залежності від інтонації та голосу мовця) (Lozova, 2011); «митниця» (3 учасників обираються два «працівника митниці» та два 
«іноземці». Завдання перших полягає у проведенні бесіди 3 іноземцями 3 метою з'ясування, хто з них провозить «контрабанду». Зазначена вправа-гра сприяє виробленню професійно значущого вміння вчителя визначати почуття співрозмовників за зовнішніми ознаками поведінки); «конфлікт» (майбутні вчителі працюють у мікрогрупах, що складаються з трьох осіб: керівник та два конфліктуючих. Керівник має з'ясувати реальне становище речей, дати об’єктивну оцінку ситуації, що склалася. Конфліктуючі аргументують власну позицію. Участь в окресленій вправі-грі привчає майбутніх учителів до пошуку шляхів розв'язання неординарних конфліктних ситуацій) (Kichuk, 1999; Laurillard, 2012).

Друга група включає вправи, які сприяють розвитку педагогічної уяви, інтуїції, навичок педагогічної імпровізації (Edge, Garton, 2012; Ortynskyi, 2009): педагогічні задачі та педагогічні ситуації комунікативного спрямування (Kichuk, 1999; Kohut, 2015).

Особливу роль у формуванні вмінь майбутніх учителів налагоджувати взаємини з учнями та здійснювати виховний вплив ми надаємо вирішенню педагогічних ситуацій-вправ комунікативного спрямування, що дають можливість учителям прогнозувати та моделювати власну поведінку, сприяють розвитку їх рефлексивних здібностей.

Наприклад, ситуація-вправа 1. Поясніть, як Ви будете діяти під час такої ситуації. Знайдіть варіант іï вирішення. Поясніть обрану позицію та опишіть власний емоційний стан у даному випадку.

«Іде урок української мови. Після пояснення нового матеріалу вчитель дає учням завдання. У процесі відповідей однокласників хлопець встає та починає ходити по класу. На зауваження вчителя, він відповідає, що втомився від сидіння та хоче ходити».

Ситуація-вправа 2. Як Ви будете поводити себе у даній ситуації? Які заходи повинен вжити вчитель? 
«Учитель роздає учням завдання для контрольної роботи з іноземної мови. Через декілька хвилин дівчина здає зошит. Вона пояснює, що нічого не розуміє і не знає, що писати».

Ситуація-вправа 3. Учень 10 класу, отримавши погану оцінку за контрольну роботу з іноземної мови, відмовляється писати роботу над помилками. Він говорить: «Знання мені непотрібні. У наш час - це не головне». Що повинен на це відповісти вчитель?

1. «Тобі просто не хочеться вчитися».

2. «Мені цікаво знати, чому ти так думаєш».

3. «Таких, як ти, я нічому не зможу навчити».

4. Ваш варіант.

Поясніть та аргументуйте свою відповідь.

Ситуація-вправа 4. Іде урок. Вчитель пояснює новий матеріал. Без попередження в клас тихо заходить завуч, сідає за останню парту та спостерігає за всім, що відбувається в класі, робить нотатки. Як має відреагувати вчитель? Опишіть Ваші дії, якби Ви були на місці вчителя.

Ситуація-вправа 5. Вчитель пояснює новий матеріал та просить учнів відкрити зошити та записати правило. Він помічає, що один учень не пише i запитує його: «А чому ти не пишеш?». Учень відповідає, що він буде уважно слухати, бо він так краще запам'ятовує. Як Ви вчините у даній ситуації?

Аналіз педагогічної літератури (I. Срмаков, О. Зосилеенко, Н. Краля) свідчить, що впровадження проектів у ході викладання професійноорієнтованих дисциплін для майбутніх учителів філологічних спеціальностей сприяє формуванню комунікативних умінь, розвитку творчих здібностей, підвищенню пізнавального інтересу. На основі вивчення наукових джерел (Н. Пахомова, Є. Полат) нами пропонуються такі етапи організації проектної роботи майбутніх викладачів-філологів, як: пропедевтичний, репродуктивний та креативний етап.

На пропедевтичному етапі студенти засвоюють теоретичний матеріал, обговорюють структуру проекту, складають план роботи. 
На репродуктивному етапі студенти закріплюють теоретичні знання, обговорюють проміжні результати, збирають і аналізують інформацію.

Прикінцевим етапом проектної роботи студентів є креативний. Цей етап являє собою найвищий рівень самостійної діяльності студентів, передбачає створення нової інформації; він спрямований на розробку самостійних проектів. Від майбутніх фахівців вимагається актуалізація знань і вмінь, які дозволяють їм приймати нові рішення у проблемних ситуаціях, обгрунтування власної позиції.

У процесі вивчення теми «Викладач вищого навчального закладу» в рамках навчальної дисципліни «Педагогіка вищої школи» майбутні вчителі готували індивідуальні проекти «Педагогічна комунікація - розкіш людського спілкування». Цілі проекту: формування ціннісного ставлення до педагогічної комунікації як форми контактної педагогічної взаємодії; оволодіння системою знань щодо структури, функцій та стилів педагогічної комунікації; формування вмінь та навичок подолання труднощів та бар'єрів у професійно-педагогічній комунікації вчителів та учнів.

На пропедевтичному етапі майбутні вчителі вирішували такі завдання, як: дайте визначення поняттям «педагогічна комунікація», «педагогічне спілкування»; виокремте структурні компоненти поняття «педагогічна комунікація» та дайте їх стислу характеристику. Завданнями репродуктивного етапу були такі: проаналізуйте стилі педагогічного спілкування науково-педагогічних працівників, запропоновані в дослідженнях науковців (В. Кан-Калик, Г. Мешко, В. Ортинський).

На цьому етапі майбутнім учителям пропонується перегляд художнього фільму «Суспільство мертвих поетів (Dead Poets Society)» режисера Пітера Уіра з метою аналізу стиля педагогічної комунікації вчителя англійської мови та літератури Джона Кітінга. Зазначене завдання майбутні фахівці виконували за такою схемою: особистісні якості вчителя, які сприяють, на Вашу думку, налагодити комунікацію зі студентами; методичні прийоми, котрі використовував Джон Кітінг, щоб привернути 
увагу хлопців, підвищити їх пізнавальний інтерес; особливості поведінки, зовнішності, міміки, манери спілкування вчителя зі своїми учнями в академії Велтон.

За бажанням кожен студент додає власні коментарі стосовно стилю педагогічного спілкування Джона Кітінга. На креативному етапі діяльність майбутніх учителів-філологів 3 написання індивідуальних проектів передбачала виконання таких завдань: розробка програми формування культури педагогічної комунікації вчителів; роздуми та виклад власних думок щодо ролі культури педагогічної комунікації у професійному становленні вчителя.

Висновки. Запропоновані засоби підготовки майбутніх учителівфілологів до педагогічної комунікації активізували пізнавальну самостійність, розвивали комунікативні вміння. Перспективи подальших розвідок у даному напрямі полягають у розробці та апробації комп’ютерних технологій як засобу формування готовності майбутніх учителів до педагогічної комунікації.

\section{ЛІТЕРАТУРА:}

Edge J., Garton S. From Experience to Knowledge in ELT. Oxford : Oxford University Press, 2012. 204p.

Laurillard D. Teaching as a Design Science. NY : Routledge, 2012. 255 p.

Бондарєва Л. І. Викладач як суб’єкт педагогічної комунікації. Педагогічні науки. 2010. № 120. C. 19-24.

Волкова Н. П. Професійно-педагогічна комунікація : Навч. посіб. К. : ВЦ «Академія», 2006. $256 \mathrm{c}$.

Жирун О. А. Педагогічна комунікація в аспекті професійної ідентичності. Вісник НТУУ «КПI». Філософія. Психологія. Педагогіка. 2010. № 1. С. 100-104.

Кічук Н. В. Творча особистість вчителя. Одеса, 1999. 86 с.

Когут I. В. Формування професійно-педагогічної комунікативної компетентності майбутнього вчителя: дис. канд. пед. наук : 13.00.04. Полтава, 2015. 250 с.

Мешко Г. М. Вступ до педагогічної професії : навч. посіб. К. : Академвидав, 2012. 200 с.

Мойсеюк Н. Є. Педагогіка. Навчальний посібник. К. : 2007. 656 с.

Ортинський В. Л. Педагогіка вищої школи : навч. посіб. К. : Центр учбової літератури, 2009. $472 \mathrm{c}$.

Паршук С. М., Круглова Н. С. Педагогічна комунікація як складова професійної ідентичності майбутніх учителів початкової школи. Педагогічні науки : теорія, історія, інноваційні технології. 2015. №5. С. 318-325.

Полат Е. С. Метод проектов [Электронный ресурс]. Режим доступу : http : //letopisi.ru/images/a/ac/Метод_проектов_Полат.pdf

Український педагогічний словник. За ред. С. Гончаренко. К. : Либідь, 1997. 374 с. 
Хрестоматія з педагогіки вищої школи: Навчальний посібник. За заг. ред. В. І. Лозової. Х. : Віровець А. П. «Апостроф», 2011. 408 с.

\section{REFERENCES:}

Bondareva L. I. (2010) Vykladach yak subiekt pedahohichnoi komunikatsii. [Teacher as a subject of pedagogical communication]. Pedahohichni nauky. 120. 19-24 (in Ukranian).

Edge J., Garton S. (2012) From Experience to Knowledge in ELT. Oxford : Oxford University Press (in English).

Honcharenko S. (Ed.) (1997) Ukrainskyi pedahohichnyi slovnyk. [Ukrainian Pedagogical Dictionary]. Kyiv : Lybid (in Ukranian).

Kichuk N. V. (1999) Tvorcha osobystist vchytelia. [Creative personality of the teacher]. Odesa (in Ukranian).

Kohut I. V. (2015) Formuvannia profesiino-pedahohichnoi komunikatyvnoi kompetentnosti maibutnoho vchytelia. [Formation of vocational and pedagogical communicative competence of the future teacher]. (Candidate's thesis). Poltava, Ukraine (in Ukranian).

Laurillard D. (2012) Teaching as a Design Science. NY : Routledge, 2012 (in English).

Lozova V. I. (Ed.) (2011) Khrestomatiia z pedahohiky vyshchoi shkoly. [Textbooks on higher education pedagogy]. Kharkiv : Virovets A. P. «Apostrof», 2011 (in Ukranian).

Meshko H. M. (2012) Vstup do pedahohichnoi profesii. [Introduction to the pedagogical profession]. Kyiv : Akademvydav (in Ukranian).

Moiseiuk N. Ye. (2007) Pedahohika. [Pedagogy]. Kyiv (in Ukranian).

Ortynskyi V. L. (2009) Pedahohika vyshchoi shkoly. [Pedagogy of high school]. Kyiv : Tsentr uchbovoi literatury (in Ukranian).

Parshuk C. M., Kruhlova N. C. (2015) Pedahohichna komunikatsiia yak skladova profesiinoi identychnosti maibutnikh vchiteliv pochatkovoi shkoly. [Pedagogical communication as a component of the professional identity of future teachers of elementary school]. Pedahohichni nauky : teoriia, istoriia, innovatsiini tekhnolohii. 5. 318-325 (in Ukranian).

Polat Ye. C. (N. d.) Metod proektov. [The method of projects]. (Electronic edition). Retrieved from: http : //letopisi.ru/images/a/ас/Метод_проектов_Полат.pdf(in Russian).

Volkova N. P. (2006) Profesiino-pedahohichna komunikatsiia. [Professional-pedagogical communication]. Kyiv : VTS «Akademiia» (in Ukranian).

Zhyrun O. A. (2010) Pedahohichna komunikatsiia $\mathrm{v}$ aspekti profesiinoi identychnosti. [Pedagogical communication in the aspect of professional identity]. Visnuk NTUU «KPI». 1. 100-104 (in Ukranian).

\begin{tabular}{ll}
\hline \multicolumn{1}{c}{ Інформація про автора: } & \multicolumn{1}{c}{$\begin{array}{c}\text { Information about the author: } \\
\text { Хромченко Олена Василівна: ORCID: }\end{array}$} \\
$\begin{array}{ll}\text { Khromchenko Olena Vasylivna: ORCID: } \\
\text { https://orcid.org/0000-0001-7437-6041; }\end{array}$ & $\begin{array}{l}\text { https:/orcid.org/0000-0001-7437-6041; Ph. D } \\
\text { кандидат педагогічних наук, доцент }\end{array}$ \\
in Pedagogy, Senior Lecturer of Department \\
кафедри граматики англійської мови & of English Grammar, Odesa I. I. Mechnikov \\
Одеського національного університету ім. I. & National University, Dvorianska street, Odesa, \\
I. Мечникова, вул. Дворянська, 2, м. Одеса, & Ukraine, 65000 \\
Україна, 65000 & e-mail: okne4morh@gmail.com \\
e-mail: okne4morh@gmail.com &
\end{tabular}

Цитуйте цю статтю як: Хромченко О. В. Психолого-педагогічні засоби підготовки майбутніх учителів-філологів до педагогічної комунікації. Теорія та методика навчання та виховання. 2019. № 46. С. 155-165. DOI: 10.34142/23128046.2019.46.12

Дата надходження статті до редакції: 29.03.2019

Стаття прийнята до друку: 11.04.2019 